\title{
Educational Program for School Health Nurses and Teachers Regarding Primary School Children with Epilepsy
}

\author{
Mayada Taha Mahmoud Sabea ${ }^{1, *}$, Eman Hassan Mohamoud ${ }^{2}$ \\ ${ }^{1}$ Community Health Nursing Department, Faculty of Nursing, Helwan University, Egypt \\ ${ }^{2}$ Pediatric Nursing Department, Faculty of Nursing, Helwan University, Egypt \\ *Corresponding author: mayodataha@gmail.com
}

\begin{abstract}
Epilepsy is a disorder of the brain that causes recurrent seizures. Effects people at all ages, but with higher rates at primary school age. Children with epilepsy face several social, cultural and learning problems, so that school health nurses and teachers have essential role to decrease these problems. Aim: Evaluate the educational program for school health nurses and teachers regarding primary school children with epilepsy. Design: A quasi experimental design was adopted. Setting: Governmental primary schools in Sammanoud City, Gharbia Governorate, Egypt. Sampling: Two samples were used: For school health nurses, all of them participated in the study, these were 21 school health nurses, and for teachers; simple random sample was used to select 249 teachers, with the following criteria: Direct contact with students in the class or during providing activities. Tools: An interviewing questionnaire which includes 4 parts, 1) Demographic characteristics, 2) School health nurses and teachers' knowledge about meaning of epilepsy, 3) School health nurses and teachers' attitude toward primary school children suffering from epilepsy, and 4) School health nurses and teachers' practice toward primary school children with epilepsy. Results: This study showed, highly statistically significant improvement of school health nurses and teachers' knowledge, attitude, and practices regarding epilepsy ( $4.23 \pm 1.23$ to $5.14 \pm 1.08$ and $1.49 \pm 1.07$ to $4.57 \pm 1.46$,) (6.91 \pm 1.60 to $10.68 \pm 2.06$ and $2.59 \pm 2.32$ to $9.26 \pm 2.21$ ) $(2.27 \pm 2.55$ to $3.18 \pm 2.46$ and $0.78 \pm 1.79$ to $3.27 \pm 2.38$ ) respectively post educational program implementation. Conclusion: Educational program improved the school health nurses and teachers' knowledge, attitude and practices regarding primary school children with epilepsy. The study results also showed a highly statistically significant and positive correlation between knowledge, attitude and practices of studied samples after educational program implementation. Recommendation: Dissemination of the educational program for school health nurses and teachers at all governmental and nongovernmental schools; Clarified booklet should be provided to school health nurses and teachers to deal them how to deal with children suffering from epilepsy; Training the school health nurses before work to determine how apply educational program for teachers to determine how to deal with children suffering from epilepsy during and after seizure.
\end{abstract}

Keywords: epilepsy, educational program, school health nurses and teachers, primary school children

Cite This Article: Mayada Taha Mahmoud Sabea, and Eman Hassan Mohamoud, "Educational Program for School Health Nurses and Teachers Regarding Primary School Children with Epilepsy." American Journal of Nursing Research, vol. 6, no. 5 (2018): 253-262. doi: 10.12691/ajnr-6-5-6.

\section{Introduction}

Epilepsy is a common neurological disorder affecting people of all races, communities, ages, and genders, higher commonness during primary school age. This age is a critical period because it is characterized by building the child's social, psychological, and physical life. The school period will significantly impact on the child's quality of life at all stages of child's life [1].

The brain is responsible for all minds and body functions so that the seizures can happen at any part of the brain this is shown on the client during the epileptic fit. Over 40 different types of seizures, the one person may have more than one type. Seizures are caused by malfunction of the brain's electrical system. In primary school children, it can occur with a wide variety of conditions involving the central nervous system [2].

The epileptic seizure classified as partial seizure means that epileptic activity takes place in only part of the brain, it is divided in to 2 types: Simple partial seizure, in this type the patient is conscious during the seizure; and complex partial seizure in this type the patient's consciousness is impaired. While the second type of seizure is generalized and it occurs when both halves of the brain have epileptic activity so that the client loses consciousness completely. A febrile seizure is the most common type of epilepsy in children younger than 15 years [3].

Parents should be able to determine how to handle epilepsy, to aid their child handle the epilepsy, they reflect 
their inconvenience for their child who complains from epilepsy that causes frustration for the child so that the parents should communicate with the school health nurse, teachers and the physician to help the child build selfconfidence to face the outside world [4].

The primary school children spend a lot of time at school so that the teachers have important roles for student's health through providing educational, guidance and supportive roles, also they are responsible for teaching the children how to deal with colleague complain from epileptic diseases and to communicate and interact with their peers. Also, the children with epilepsy are at risk to a decrease of educational underachievement, learning difficulties, mental health problems, social isolation, and poor self-esteem [5].

School health nurses, at governmental schools in Egypt, receive 3 years of clinical training after preparatory school with a focus on caring for clients with the most common medical health problems. There is little data about educating nurses on specific diseases such as epilepsy. Therefore, most of these nurses have gained their knowledge of epilepsy from surrounding cultures and experiences of senior colleagues [6].

In the school environment, a teacher may be the first adult to witness a child having a convulsion, each child's behavior will vary according to the type of convulsion; therefore the teacher should have the basic knowledge about the fit management to save child's life. Not only the teacher aids in management of fit but also is responsible to communicate with the school health nurse to report her about his/her observation during child's fit that aids in the diagnosis of the type and treatment of the case, also the school health nurses are the most responsible persons to improve teachers' knowledge regarding epileptic seizure through providing educational programs in the school setting [7].

\subsection{Significance of the Study}

In the United States, approximately $30 \%$ of 1, 25,000 new cases of epilepsy diagnosed each year are in children younger than 18 years. According to the World Health Organization, more than 50 million child worldwide have epilepsy and $80 \%$ of them live in developing countries. The prevalence of epilepsy, in Egypt, is 4 to $10 / 1000$ children at primary education and the essential cause of neurological morbidity in children at this age [8].

The school health nurses have positive role to support children with epilepsy through providing health education to avoid the students use their case as an excuse; help to develop self-confidence and encourage them to deal with new or difficult situations; recognize and record changes in behavior, mood and performance; and follow up the academic achievement and social interaction. The role of the school health nurse is completed in collaboration with teachers dealing with students with epilepsy [9].

\section{Aim of the Study}

The study aimed to evaluate the educational program for school health nurses and teachers regarding primary school children with epilepsy, through:
1. Assessing the school health nurses' and teachers' knowledge, attitudes and practices concerning the action done before, during and after epilepsy seizure

2. Planning and implementing an educational program to improve school health nurses' and teachers' knowledge, attitudes and practices.

3. Evaluating the effect of the educational program on improving knowledge, attitudes and practices regarding the action done before, during and after epilepsy seizure

\subsection{Research Hypothesis}

School health nurses and teachers who will take educational program will have improvement in their knowledge, attitudes and practices regarding primary school children with epilepsy

\subsection{Subjects and Methods}

\subsubsection{Design}

A quasi experimental design was adopted to carry out this study.

\subsubsection{Setting}

The study was conducted at governmental primary schools in Sammanoud City, Gharbia Governorate, Egypt. The primary schools in Sammanoud City are 13 general primary schools with 531 teachers at all grades and 21 school health nurses.

\subsubsection{Sample}

Two samples were used for:

- School health nurses: All of them participated in the study; these were 21 school health nurses.

- Teachers: A simple random sample was used to select 249 teachers with the following criteria: Direct contact with students in the class or during providing activities.

\subsubsection{Sample Size Calculation}

Based on [10], the following equation was used for the sample size of teachers calculation, where confidence level and $\mathrm{p}=0.5$ assured.

$$
\mathrm{n}=\mathrm{N} / 1+\mathrm{N}(\mathrm{e})^{2}
$$

Where:

$\mathrm{n}$ = Sample size

$\mathrm{N}=$ Population size

$\mathrm{e}=$ Level of precision $=0.05$

Accordingly, the estimated sample size is 249 teachers who were included in the study.

\subsubsection{Tools of Data Collection}

An interviewing questionnaire that consisted 4 parts:

- Part 1: Demographic characteristics for school health nurses and teachers such as; age, sex, level of education, years of experience and position of teachers.

- Part 2: School health nurses and teacher's knowledge about meaning of epilepsy, types, causes, 
clinical picture, complications, and the actions taken (before, during and after the epileptic seizure).

\subsubsection{Scoring System}

The tool of knowledge included 7 questions, a correct answer scored one, while didn`t know or wrong answer scored zero. The scores of the items were summed up and the total divided by the number of items. These scores were converted into a percent score. A score of $60: 75 \%$ was considered fair; while more than $75 \%$ reflected good knowledge and poor if less than 60\%.

- Part 3: School health nurses and teacher's attitude toward primary school children with epilepsy such as; Neglecting, allow to use the illness as an excuse, dealing with the child with epilepsy differently than his/her colleagues, avoid encouraging the children with epilepsy to participate in different activities, avoid dealing along with epileptic seizure, stay calm and avoid helping the children with epilepsy, don't speak quietly and calmly with the student, feel fear and panic from epileptic case, and don't encourage the students to communicate with the child complaining from epilepsy

\subsubsection{Scoring System}

The attitude tool consists of 9 questions asked for the studied sample, never response scored "zero", while sometimes scored "1" and always scored "2", if the subject answered sometimes or always following the attitude that leads to negative attitude, and if the sample reported never that leads to positive attitude, the scores of the items were summed up and the total divided by the number of the items giving a mean score for the part. These scores were converted into a percent score. The attitude was considered positive attitude if the percent score was $50-100 \%$, and negative attitude if less than $50 \%$.

- Part 4: School health nurses and teacher's practices toward primary school children with epilepsy it is divided to:

A) Practices questionnaire for school health nurse and teachers, it consists of:

- Practice during the seizure: Move objects like furniture away from the case, don't move the case during the seizure, note the time the seizure starts, put anything (such as tongue depressor, gauze or clothes pieces) in the child's mouth...etc.

- Practice after seizure:

- Toward the case: Put the child into the recovery position, check that breathing is returning to normal, gently check mouth to see that nothing is blocking airway such as; food or false teeth, if breathing is difficult after the seizure has stopped, call for an ambulance, stay with him/her until fully recovered, help the person sit in a safe place, once is alert and able to communicate, tell the child what happened in very simple terms, ...etc.

- Toward the case colleagues: Explain the case to the student's colleagues to avoid fear ...etc.

B) Practices questionnaire for school health nurse only such as: Educate the teacher and other staff how deal with students with epilepsy, communicate with parents of student with epilepsy, Perform the child's health records, the health records updated and corrected.

\subsubsection{Scoring System}

This part contains 20 questions were scored as: zero if the subject reported a not done practice, while scored "1" when a reported answer was a done practice. The scores of the items were summed up and the total divided by the number of the items giving a mean score for the part. These scores were converted into a percent score. The practice levels considered bad if the percent score was less than $50 \%$, moderate practice level if the percent score was $50-<75 \%$ and good practice levels if equal or more than $75 \%$.

\subsection{Validity}

Tools were tested for content validity, by a Jury of 5 experts in the community and pediatric health nursing field; and pediatric and neurology medicine, to confirm the consequence and comprehensiveness of the tools.

\subsection{Reliability}

Reliability was applied by the researchers to assess reliability of the study tools of:

- School health nurses and teacher's knowledge, Cronbach's Alpha was 0.823 .

- School health nurses and teacher's attitude, Cronbach's Alpha which was 0.897.

- School health nurses and teacher's practice, Cronbach's Alpha which was 0.835

\subsection{Pilot Study}

A pilot study was carried out on $10 \%$ of the studied sample in the different governmental primary schools in Sammnoud City, Gharbeia Governorate, to test clarity, applicability and comprehensiveness of the tools. As well the time needed to fill in the questionnaire was determined. No modifications were applied on the study tools in accordance with the pilot study; however the piloted subjects were excluded from the main study sample.

\subsection{Ethical Considerations}

The purpose of the study was explained to the sample and an oral consent to participate in the study was obtained. The agreement for participation of the subjects was taken after aim of the study has been explained to them by the researchers. They were given an opportunity to refuse to participate and they were assured that given the information would be treated confidentially and used for the research purpose only.

\subsection{Field Work}

- Official permission to carry out the study was taken from each school director upon an issued letter from the Faculty of Nursing, Helwan University containing the aim, content, time plan of the program. 
- Preparation of data collection was carried out from the beginning of September 2016 to the end of March 2017.

- The researchers conducted the educational program for the studied sample at primary schools in Sammnoud City 2 days/week (Saturdays \& Mondays) from 10.00 a.m. to 1.00 p.m., each session took from 45-60 minutes. Each school was visited 5 times.

- The researchers applied the educational program for teachers at library or at school theater in some studied settings and conduct the educational program for nurses at school health nurse clinic.

\section{The field work was conducted in 5 phases}

- Assessment phase: At the beginning of this phase the researchers greeted the studied sample, then introduced themselves for the school health nurses and teachers, also they explained the purpose of research, and they filled in the questionnaire related to demographic data and implementation of the pretest questionnaire to identify the studied samples' knowledge, attitudes and practices regarding the primary school children with epilepsy. They informed the study sample about what will be provided at the next visit.

- Planning and implementation phase: The educational program was implemented to improve the school health nurses' and teachers' knowledge, attitudes and practices regarding primary school children with epilepsy. It included:

- School health nurses' and teachers' knowledge as: meaning of epilepsy, types, causes, clinical picture, complications, and the actions to be taken before, during and after the epileptic seizure.

- School health nurses' and teachers' attitudes as: Importance of avoiding neglect of the children with epilepsy, don't allow to the student with epilepsy to make his/ her illness as an excuse, importance of dealing the child with epilepsy like his/her colleagues, encourage the students with epilepsy to participate in different activities...etc.

- School health nurses' and teachers' reported practice that cover, seizures phases. During the phase such as: Importance of moving objects like furniture away from the case, etc. After the phase as: Toward the case: Put the child with epilepsy into the recovery position, check breathing is returning to normal...etc., toward the case colleagues: Explain the case to the student's colleagues to avoid fear...etc.

- $\quad$ Reported practice more specific for school health nurses only, such as: Educate the teachers and other staff how deals with students with epilepsy, communicate with parents of child with epilepsy, etc.

- Implementation phase of the educational program lasted 7 months in 6 sessions. Each session takes from 45-60 minutes. The researchers started by a summary about what was provided at previous one, and showed the objectives of the new session, taking in to consideration using simple and clear language.
- Different teaching methods were used to the small groups as: discussion, brain storming, demonstration and re-demonstration. The researchers were using brochures, and a laptop screen for data show. A booklet was distributed to all studied sample. At the end of each session, the researchers tell the studied sample what will be provided the next session, its content and time defined.

- Evaluation phase: This phase was conducted 2 weeks after the educational program implementation through using the same pre educational program tools.

\subsection{Statistical Analysis}

The collected data were organized, tabulated and statistically analyzed using Statistical Package for the Social Sciences (SPSS), version 19, (SPSS Inc. Chicago, IL, USA). For quantitative data, the range, mean and standard deviation were calculated. For qualitative data, which describe a categorical set of data by frequency, percentage or proportion of each category, comparison between two groups and more was done using Chi-square test $\left(\chi^{2}\right)$. For comparison between means of two groups of parametric data of independent samples, student t-test was used. For comparison between means of two groups of non-parametric data of independent samples, Z-value of Mann-Whitney test was used. For comparison between means of two related groups (before and after data) of parametric data, paired t-test was used. For comparison between means of two related groups (before \& after intervention) of non-parametric data, $\mathrm{Z}$ value of Wilcoxon Signed Ranks Test was used. For comparison between more than two means of parametric data, F-value of ANOVA test was calculated. For comparison between more than two means of non-parametric data, Kruskal-Wallis ( $\chi^{2}$ value) was calculated. Correlation between variables was evaluated using Pearson's correlation coefficient (r). Significance was adopted at $\mathrm{p}<0.05$ for interpretation of results of tests of significance [11].

\subsection{Results}

Table 1: Presents demographic data of the studied school health nurses and teachers. It was observed that $41.8 \%$ of the teachers were aged 30 years to less than 40 years, while $86.4 \%$ of the school health nurses were aged 40 years to less than 50 years. Regarding sex, $61.4 \%$ of the studied teachers were females, and $46.6 \%$ of teachers were having University bachelor, while $5.6 \%$ of them have intermediate diploma.

Table 2: Shows statistically significant improvements in change of total knowledge score of the studied school health nurses and teachers.in the post - test than those of the pre - test $(\mathrm{P}<0.001)$.

Table 3: Displays the statistically significant improvements in change of total attitude score of the studied school health nurses and teachers.in the post-test than those of the pre-test $(\mathrm{P}<0.001)$.

Table 4: Shows statistically insignificant improvements in total score practices of studied sample towards diseased child during and after the seizure and the child's colleagues after the seizure $(0.863,0.581 \& 0.297$ respectively). 
Table 1. Demographic Data of the Studied School Health Nurses and Teachers $(n=271)$

\begin{tabular}{|c|c|c|c|c|c|}
\hline \multirow{3}{*}{ Variables } & \multicolumn{4}{|c|}{$\begin{array}{c}\text { Studied subjects } \\
(n=271)\end{array}$} & \multirow{3}{*}{$\begin{array}{l}\chi^{2} \\
\mathbf{P}\end{array}$} \\
\hline & \multicolumn{2}{|c|}{$\begin{array}{l}\text { School health nurses } \\
(\mathrm{n}=22)\end{array}$} & \multicolumn{2}{|c|}{$\begin{array}{c}\text { Teachers } \\
(n=249)\end{array}$} & \\
\hline & $\mathbf{n}$ & $\%$ & $\mathbf{n}$ & $\%$ & \\
\hline Age years: & & & & & \multirow{5}{*}{$\begin{array}{c}39.479 \\
0.0001^{*}\end{array}$} \\
\hline $25-$ & 0 & 0 & 45 & 18.1 & \\
\hline $30-$ & 1 & 4.5 & 104 & 41.8 & \\
\hline $40-$ & 19 & 86.4 & 59 & 23.7 & \\
\hline $50-$ & 2 & 9.1 & 41 & 16.5 & \\
\hline \multicolumn{6}{|l|}{ Sex: } \\
\hline Males & 0 & 0 & 96 & 38.6 & 13.135 \\
\hline Females & 22 & 100 & 153 & 61.4 & $0.0001 *$ \\
\hline Education level: & & & & & \multirow{5}{*}{$\begin{array}{l}156.300 \\
0.0001^{*}\end{array}$} \\
\hline Intermediate diploma & 22 & 100 & 14 & 5.6 & \\
\hline University bachelor & 0 & 0 & 116 & 46.6 & \\
\hline Post graduate diploma & 0 & 0 & 74 & 29.7 & \\
\hline Master degree & 0 & 0 & 45 & 18.1 & \\
\hline \multicolumn{6}{|l|}{ Years of experience: } \\
\hline $1-<3$ & 0 & 0 & 50 & 20.1 & \multirow{3}{*}{$\begin{array}{c}22.076 \\
0.0001^{*}\end{array}$} \\
\hline $3-<7$ & 0 & 0 & 80 & 32.1 & \\
\hline $7+$ & 22 & 100 & 119 & 47.8 & \\
\hline \multicolumn{6}{|l|}{ Position of teachers: } \\
\hline Teacher & 0 & 0 & 50 & 20.1 & 271.000 \\
\hline Senior teacher & 0 & 0 & 80 & 32.1 & $0.0001^{*}$ \\
\hline Activity teacher & 0 & 0 & 119 & 47.8 & \\
\hline
\end{tabular}

*Significant $\mathrm{P}<0.05$.

Table 2. Total Knowledge Scores Among the Studied School Health Nurses and Teachers about Epilepsy Pre and Post Educational Program $(\mathbf{n}=\mathbf{2 7 1})$

\begin{tabular}{|c|c|c|c|c|c|c|c|c|c|c|c|c|}
\hline \multirow{4}{*}{ Total knowledge } & \multicolumn{10}{|c|}{ Total knowledge of the studied subjects pre/post educational program $(n=271)$} & \multirow{2}{*}{\multicolumn{2}{|c|}{$\begin{array}{c}\chi^{2} \\
\mathbf{P} \\
\text { (Teachers vs Nurses) }\end{array}$}} \\
\hline & \multicolumn{5}{|c|}{$\begin{array}{l}\text { School health nurses } \\
\qquad(\mathrm{n}=22)\end{array}$} & \multicolumn{5}{|c|}{$\begin{array}{c}\text { Teachers } \\
(n=249)\end{array}$} & & \\
\hline & \multicolumn{2}{|c|}{ Pre } & \multicolumn{2}{|c|}{ Post } & $\chi^{2}$ & \multicolumn{2}{|c|}{ Pre } & \multicolumn{2}{|c|}{ Post } & $\chi^{2}$ & \multirow{2}{*}{ Pre } & \multirow{2}{*}{ Post } \\
\hline & No. & $\%$ & No. & $\%$ & $\mathbf{P}$ & No. & $\%$ & No. & $\%$ & $\mathbf{P}$ & & \\
\hline Poor & 11 & 50.0 & 5 & 22.7 & \multirow{3}{*}{$\begin{array}{c}6.763 \\
0.034^{*}\end{array}$} & 230 & 92.4 & 113 & 45.4 & \multirow{3}{*}{$\begin{array}{c}136.307 \\
0.001\end{array}$} & \multirow{3}{*}{$\begin{array}{l}48.384 \\
0.001^{*}\end{array}$} & \multirow{3}{*}{$\begin{array}{l}4.220 \\
0.121\end{array}$} \\
\hline Fair & 9 & 40.9 & 8 & 36.4 & & 19 & 7.6 & 64 & 25.7 & & & \\
\hline Good & 2 & 9.1 & 9 & 40.9 & & 0 & 0 & 72 & 28.9 & & & \\
\hline Total knowledge scores: & \multicolumn{2}{|c|}{$\begin{array}{c}0-6 \\
4.23 \pm 1.23\end{array}$} & \multicolumn{2}{|c|}{$\begin{array}{c}2-7 \\
5.14 \pm 1.08\end{array}$} & & \multicolumn{2}{|c|}{$\begin{array}{c}0-6 \\
1.49 \pm 1.07\end{array}$} & \multicolumn{2}{|c|}{$\begin{array}{c}0-7 \\
4.57 \pm 1.46\end{array}$} & & \multicolumn{2}{|c|}{$\begin{array}{c}\text { t-test } \\
P\end{array}$} \\
\hline $\begin{array}{l}\text { Paired t-test } \\
\mathrm{P}\end{array}$ & \multicolumn{4}{|c|}{$\begin{array}{c}2.601 \\
0.013^{*}\end{array}$} & & \multicolumn{4}{|c|}{$\begin{array}{l}15.535 \\
0.001 *\end{array}$} & & $0.001^{*}$ & 0.078 \\
\hline \multicolumn{13}{|l|}{$\begin{array}{l}\text { Change of knowledge } \\
\text { scores post intervention: }\end{array}$} \\
\hline $\begin{array}{l}\text { Range (0-7) } \\
\text { Mean } \pm \text { SD }\end{array}$ & \multicolumn{4}{|c|}{$\begin{array}{c}0-3 \\
0.91 \pm 0.81\end{array}$} & & \multicolumn{4}{|c|}{$\begin{array}{c}0-7 \\
3.08 \pm 1.57 \\
\end{array}$} & & & \\
\hline $\begin{array}{l}\text { t-test } \\
\mathrm{P}\end{array}$ & & & & & $\begin{array}{c}6.068 \\
0.001^{*}\end{array}$ & & & & & & & \\
\hline
\end{tabular}

*Significant $\mathrm{P}<0.05$. 
Table 3. Total Attitude Scores of the Studied School Health Nurses and Teachers about Epilepsy Pre and Post Educational Program (n=271).

\begin{tabular}{|c|c|c|c|c|c|c|c|c|c|c|c|c|}
\hline \multirow{4}{*}{ Total attitude } & \multicolumn{10}{|c|}{ Total attitude of the studied subjects pre and post- educational program $(n=271)$} & \multirow{2}{*}{\multicolumn{2}{|c|}{$\begin{array}{c}\chi^{2} \\
\mathbf{P} \\
\text { (Nurses vs Teachers) }\end{array}$}} \\
\hline & \multicolumn{5}{|c|}{$\begin{array}{l}\text { School health nurses } \\
(n=22)\end{array}$} & \multicolumn{5}{|c|}{$\begin{array}{l}\text { Teachers } \\
(n=249)\end{array}$} & & \\
\hline & \multicolumn{2}{|c|}{ Pre } & \multicolumn{2}{|c|}{ Post } & \multirow{2}{*}{$\frac{\chi^{2}}{\mathbf{P}}$} & \multicolumn{2}{|c|}{ Pre } & \multicolumn{2}{|c|}{ Post } & \multirow{2}{*}{$\frac{\chi^{2}}{\mathbf{P}}$} & \multirow[t]{2}{*}{ Pre } & \multirow[t]{2}{*}{ Post } \\
\hline & No. & $\%$ & No. & $\%$ & & No. & $\%$ & No. & $\%$ & & & \\
\hline \multicolumn{13}{|l|}{ Total attitude levels: } \\
\hline Negative & 19 & 85.4 & 2 & 9.1 & 26.327 & 242 & 97.2 & 90 & 36.1 & 208.77 & 6.665 & 6.598 \\
\hline Positive & 3 & 13.6 & 20 & 90.9 & $0.0001^{*}$ & 7 & 2.8 & 159 & 63.9 & $0.0001 *$ & $0.010^{*}$ & $0.010 *$ \\
\hline Total attitude scores: & & & & & & & & & & & \multicolumn{2}{|c|}{$\begin{array}{c}\text { t-test } \\
P\end{array}$} \\
\hline $\begin{array}{l}\text { Range (0-18) } \\
\text { Mean } \pm \text { SD }\end{array}$ & \multicolumn{2}{|c|}{$\begin{array}{c}1 \\
4-10 \\
6.91 \pm 1.60\end{array}$} & \multicolumn{2}{|c|}{$\begin{array}{c}-16 \\
10.68 \pm 2.06\end{array}$} & & $\begin{array}{r}1- \\
2.59\end{array}$ & 2.32 & \multicolumn{2}{|c|}{$\begin{array}{c}3-14 \\
9.26 \pm 2.21\end{array}$} & & $\begin{array}{c}8.543 \\
0.0001 *\end{array}$ & $\begin{array}{c}2.903 \\
0.004 *\end{array}$ \\
\hline $\begin{array}{l}\text { Paired t-test } \\
\mathrm{P}\end{array}$ & \multicolumn{4}{|c|}{$\begin{array}{c}6.791 \\
0.0001 *\end{array}$} & & \multicolumn{4}{|c|}{$\begin{array}{c}1 \\
32.831 \\
0.0001^{*}\end{array}$} & & & \\
\hline \multicolumn{13}{|l|}{$\begin{array}{l}\text { Change of attitude score } \\
\text { post intervention: }\end{array}$} \\
\hline $\begin{array}{l}\text { Range } \\
\text { Mean } \pm \text { SD }\end{array}$ & \multicolumn{4}{|c|}{$\begin{array}{c}0-9 \\
3.77 \pm 1.99\end{array}$} & & \multicolumn{4}{|c|}{$\begin{array}{c}0: 13 \\
6.67 \pm 2.37 \\
\end{array}$} & & & \\
\hline $\begin{array}{l}\text { t-test } \\
\mathrm{P}\end{array}$ & & & & & $\begin{array}{c}5.573 \\
0.0001^{*}\end{array}$ & & & & & & & \\
\hline
\end{tabular}

*Significant $\mathrm{P}<0.05$.

Table 4. Practice of the Studied School Health Nurses and Teachers towards Epileptic Child Pre and Post Educational Program (n=271)

\begin{tabular}{|c|c|c|c|c|c|c|c|c|}
\hline \multirow{3}{*}{ Practice sub items } & \multicolumn{6}{|c|}{$\begin{array}{l}\text { Total practice of the studied subjects pre and post educational program } \\
(\mathrm{n}=271)\end{array}$} & \multirow{2}{*}{\multicolumn{2}{|c|}{$\begin{array}{c}\text { Z value } \\
\mathbf{P} \\
\text { Nurses vs Teacher }\end{array}$}} \\
\hline & \multicolumn{3}{|c|}{$\begin{array}{c}\begin{array}{c}\text { School health nurses } \\
(n=22)\end{array} \\
\end{array}$} & \multicolumn{3}{|c|}{$\begin{array}{l}\text { Teachers } \\
(n=249)\end{array}$} & & \\
\hline & Pre & Post & $\begin{array}{l}\text { \#Z value } \\
\text { P }\end{array}$ & Pre & Post & $\begin{array}{l}\text { \#Z value } \\
\text { P }\end{array}$ & Pre & Post \\
\hline \multicolumn{9}{|c|}{ A-Practices during the seizure: } \\
\hline Range (0-5) & $0-5$ & $0-5$ & 1.203 & $0-5$ & $0-5$ & 11.517 & 3.519 & 0.172 \\
\hline Mean \pm SD & $2.27 \pm 2.55$ & $3.18 \pm 2.46$ & 0.236 & $0.78 \pm 1.79$ & $3.27 \pm 2.38$ & $0.0001 *$ & $0.0001^{*}$ & 0.863 \\
\hline \multicolumn{9}{|c|}{$\begin{array}{l}\text { B-Practices after seizure towards the } \\
\text { diseased child: }\end{array}$} \\
\hline Range (0-13) & $0-2$ & $4-13$ & 12.449 & $0-2$ & $3-13$ & 19.546 & 0.110 & 0.552 \\
\hline Mean \pm SD & $1.14 \pm 0.94$ & $8.64 \pm 2.66$ & $0.0001^{*}$ & $1.11 \pm 0.93$ & $8.96 \pm 2.41$ & $0.0001^{*}$ & 0.908 & 0.581 \\
\hline \multicolumn{9}{|c|}{$\begin{array}{l}\text { C-Practices after seizure towards the } \\
\text { student's colleagues: }\end{array}$} \\
\hline Range (0-2) & $0-1$ & $0-2$ & 5.945 & $0-1$ & $0-2$ & 15.944 & 0.344 & 1.043 \\
\hline Mean \pm SD & $0.14 \pm 0.35$ & $1.36 \pm 0.90$ & $0.0001 *$ & $0.16 \pm 0.37$ & $1.53 \pm 0.83$ & 0.0001* & 0.731 & 0.297 \\
\hline
\end{tabular}

*Significant $\mathrm{P}<0.05$, Z value of Mann-Whitney $\mathrm{U}$ test, \#Z value of Wilcoxon test.

Table 5. Total Practice Scores among the Studied School Health Nurses and Teachers toward Epileptic Child Pre and Post Educational Program $(n=271)$

\begin{tabular}{|c|c|c|c|c|c|c|c|c|c|c|c|c|}
\hline \multirow{4}{*}{ Total practice } & \multicolumn{10}{|c|}{ Total practice of the studied subjects pre and post- educational program $(n=271)$} & \multirow{2}{*}{\multicolumn{2}{|c|}{$\begin{array}{c}\chi^{2} \\
\mathbf{P} \\
\text { (Nurses vs } \\
\text { Teachers) }\end{array}$}} \\
\hline & \multicolumn{5}{|c|}{$\begin{array}{c}\text { School health nurses } \\
(n=22)\end{array}$} & \multicolumn{5}{|c|}{$\begin{array}{l}\text { Teachers } \\
(n=249)\end{array}$} & & \\
\hline & \multicolumn{2}{|c|}{ Pre } & \multicolumn{2}{|c|}{ Post } & \multirow{2}{*}{$\frac{\chi^{2}}{\mathbf{P}}$} & \multicolumn{2}{|c|}{ Pre } & \multicolumn{2}{|c|}{ Post } & \multirow{2}{*}{$\frac{\chi^{2}}{\mathbf{P}}$} & \multirow{2}{*}{ Pre } & \multirow[t]{2}{*}{ Post } \\
\hline & No. & $\%$ & No. & $\%$ & & No. & $\%$ & No. & $\%$ & & & \\
\hline \multicolumn{13}{|l|}{ Total practice levels: } \\
\hline Bad & 22 & 100 & 4 & 18.2 & 30.462 & 249 & 100 & 34 & 13.7 & 378.339 & - & 0.639 \\
\hline Moderate & 0 & 0 & 12 & 54.5 & $0.0001^{*}$ & 0 & 0 & 129 & 51.8 & $0.0001^{*}$ & & 0.727 \\
\hline Good & 0 & 0 & 6 & 27.3 & & 0 & 0 & 86 & 34.5 & & & \\
\hline Total practice scores: & & & & & & & & & & & & \\
\hline $\begin{array}{l}\text { Range (0-20) } \\
\text { Mean } \pm \text { SD }\end{array}$ & \multicolumn{2}{|c|}{$\begin{array}{c}1 \\
0-7 \\
3.55 \pm 2.32\end{array}$} & \multicolumn{2}{|c|}{$\begin{array}{c}-19 \\
13.18 \pm 4.04\end{array}$} & & \multicolumn{2}{|c|}{$\begin{array}{c}0-8 \\
2.06 \pm 2.00\end{array}$} & \multicolumn{2}{|c|}{$\begin{array}{c}4-20 \\
13.76 \pm 3.56\end{array}$} & & $\begin{array}{c}2.889 \\
0.004 *\end{array}$ & $\begin{array}{l}0.571 \\
0.568\end{array}$ \\
\hline $\begin{array}{l}\text { Paired t-test } \\
\mathrm{P}\end{array}$ & \multicolumn{4}{|c|}{$\begin{array}{c}5.402 \\
0.0001^{*}\end{array}$} & & \multicolumn{4}{|c|}{$\begin{array}{c}19.183 \\
0.0001 *\end{array}$} & & & \\
\hline \multicolumn{13}{|c|}{$\begin{array}{l}\text { Change of total practice score } \\
\text { post-intervention: }\end{array}$} \\
\hline $\begin{array}{l}\text { Range } \\
\text { Mean } \pm \text { SD }\end{array}$ & \multicolumn{4}{|c|}{$\begin{array}{c}0: 15 \\
7.14 \pm 3.78\end{array}$} & & \multicolumn{4}{|c|}{$\begin{array}{c}2: 20 \\
11.70 \pm 3.71\end{array}$} & & & \\
\hline $\begin{array}{l}\text { t-test } \\
P\end{array}$ & \multicolumn{9}{|c|}{$\begin{array}{c}5.522 \\
0.0001 *\end{array}$} & & & \\
\hline
\end{tabular}

*Significant $\mathrm{P}<0.05$. 
Table 6. Correlation in Total Scores of Knowledge, Attitudes and Practices of the Studied School Health Nurses and Teachers about Epilepsy Post Educational Program $(\mathbf{n}=\mathbf{2 7 1})$

\begin{tabular}{|c|c|c|c|c|c|c|c|c|}
\hline \multirow{3}{*}{ Variables } & \multicolumn{4}{|c|}{ Total practice of the studied subjects pre and post- educational program (n=271) } \\
\cline { 2 - 9 } & \multicolumn{4}{|c|}{$\begin{array}{c}\text { School health nurses } \\
\text { (n=22) }\end{array}$} & \multicolumn{4}{c|}{$\begin{array}{c}\text { Teachers } \\
(\mathbf{n}=249)\end{array}$} \\
\cline { 2 - 9 } & Total knowledge scores & Total practice scores & \multicolumn{2}{c|}{ Total knowledge scores } & \multicolumn{2}{c|}{ Total practice scores } \\
\cline { 2 - 9 } & $\mathrm{r}$ & $\mathrm{P}$ & $\mathrm{r}$ & $\mathrm{P}$ & $\mathrm{r}$ & $\mathrm{P}$ & $\mathrm{r}$ & $\mathrm{P}$ \\
\hline Total practice scores & 0.451 & $0.035^{*}$ & - & & 0.253 & $0.0001^{*}$ & - & - \\
\hline Total attitude scores & 0.279 & 0.208 & 0.159 & 0.480 & 0.021 & 0.741 & 0.010 & 0.881 \\
\hline
\end{tabular}

*Significant $\mathrm{P}<0.001$, $\mathrm{r}=$ Pearson Correlation Coefficient.

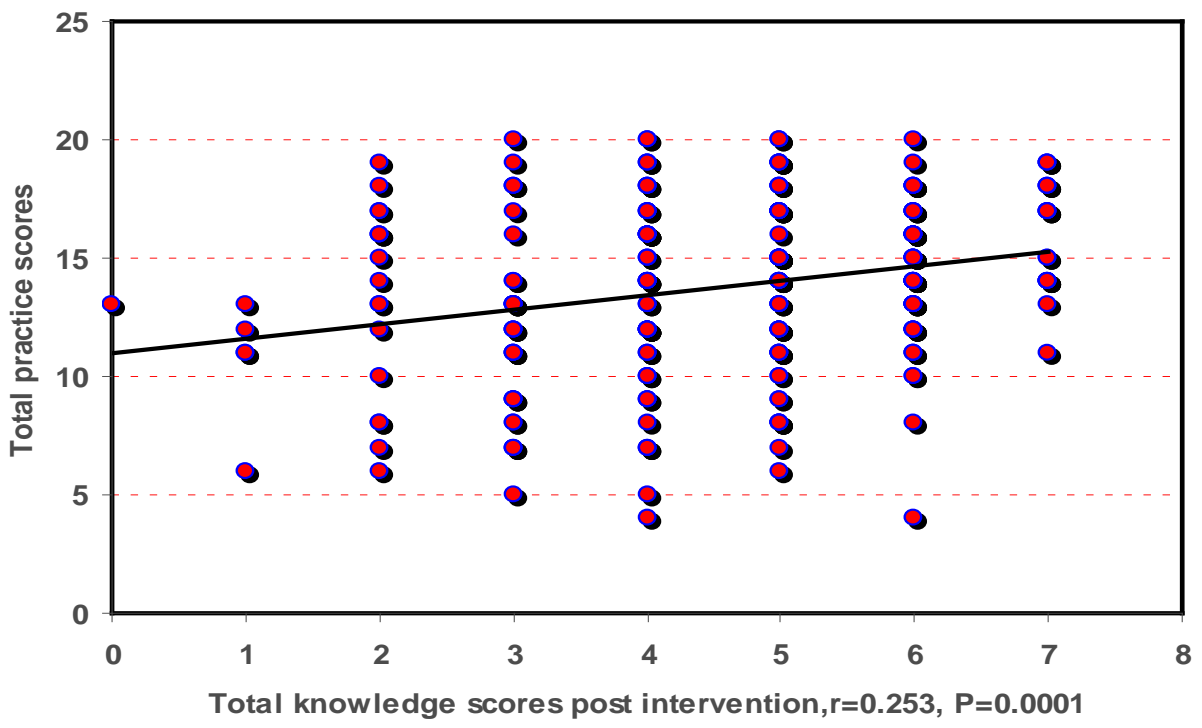

Figure 1. Correlation between Total Scores of Knowledge and Practice about Epilepsy Post Educational Program among the Teachers ( $\mathrm{n}=249)$

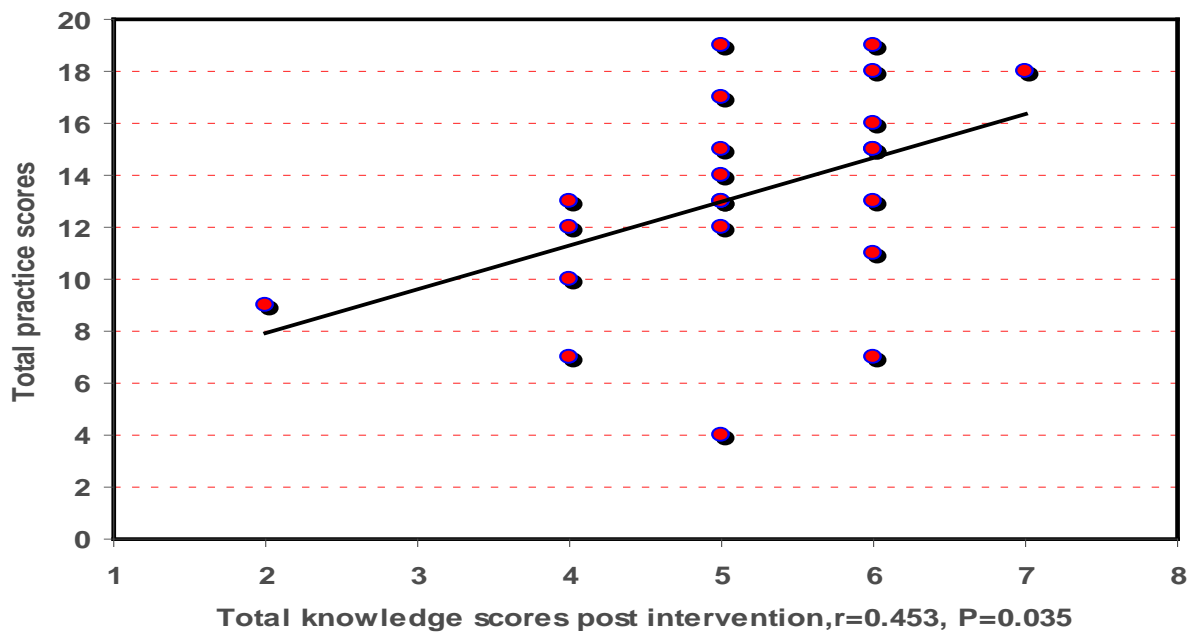

Figure 2. Correlation between Total Scores of Knowledge and Practice about Epilepsy Post Educational Program among the School Health Nurses $(\mathrm{n}=22)$

Table 5: Demonstrates statistically significant improvements in change of total practice score of the studied sample in the post-test than that of the pre - test $(\mathrm{P}<0.001)$.

Table 6: Shows significant correlations between total knowledge score and total practice score among the school health nurses and teachers. (0.001 and 0.035 respectively), while there were insignificant correlations between total practice score and total attitude score among the studied subjects regarding epilepsy post educational program

Figure 1: Displays positive improvement correlation between total knowledge score and total practice score among the teachers regarding epilepsy post educational program $(r=253$ at $\mathrm{P}=0.0001)$.

Figure 2: Reveals positive correlations improvements between total knowledge score and total practice score among the school health nurses regarding epilepsy post educational program ( $\mathrm{r}=453$ at $\mathrm{P}=0.053)$.

Table 7: Shows statistically significant relations among the studied teachers total attitude score and all demographic data except sex as: Age, educational level, years of experience, and position of teachers $(0.004,0.001,0.013$ \& 0.012 respectively), while there was significant correlation among the studied teachers and some demographic characteristics as educational level and years of experience. 
Table 7. Relations between Total Scores of Knowledge, Attitudes and Practices and some of the demographic characteristics of the Studied Teachers about Epilepsy Post Educational Program (n=249)

\begin{tabular}{|c|c|c|c|c|c|c|}
\hline \multirow{3}{*}{ Variables } & \multicolumn{6}{|c|}{ 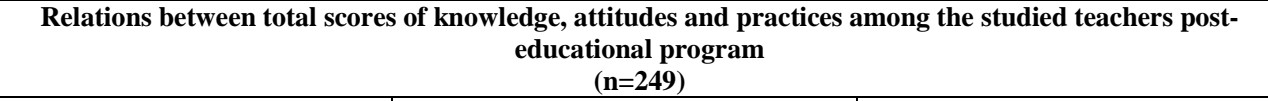 } \\
\hline & \multicolumn{2}{|c|}{ Total knowledge scores } & \multicolumn{2}{|c|}{ Total attitude scores } & \multicolumn{2}{|c|}{ Total practice scores } \\
\hline & $\operatorname{Mean} \pm$ SD & $\begin{array}{l}\text { t-test or } \\
\text { F-value } \\
\quad \text { P }\end{array}$ & Mean \pm SD & $\begin{array}{l}\text { t-test or } \\
\text { F-value } \\
\quad \text { P }\end{array}$ & Mean \pm SD & $\begin{array}{l}\text { t-test or } \\
\text { F-value } \\
\text { P }\end{array}$ \\
\hline \multicolumn{7}{|l|}{ Age (in years): } \\
\hline 25- & $2.60 \pm 1.48$ & 2.219 & $5.71 \pm 2.09$ & 4.582 & $10.87 \pm 3.71$ & 1.235 \\
\hline $30-$ & $3.08 \pm 1.57$ & 0.086 & $6.71 \pm 2.48$ & $0.004 *$ & $11.80 \pm 3.62$ & 0.298 \\
\hline $40-$ & $3.37 \pm 1.69$ & & $7.41 \pm 2.26$ & & $12.25 \pm 3.77$ & \\
\hline $50-$ & $3.22 \pm 1.42$ & & $6.59 \pm 2.20$ & & $11.59 \pm 3.83$ & \\
\hline \multicolumn{7}{|l|}{ Sex: } \\
\hline Males & $3.10 \pm 1.50$ & 0.157 & $6.98 \pm 2.50$ & 1.612 & $11.58 \pm 3.54$ & 0.402 \\
\hline Females & $3.07 \pm 1.62$ & 0.875 & $6.48 \pm 2.27$ & 0.108 & $11.78 \pm 3.82$ & 0.688 \\
\hline \multicolumn{7}{|l|}{ Education level: } \\
\hline Intermediate diploma & $3.57 \pm 1.83$ & 2.674 & $5.64 \pm 2.76$ & 6.066 & $12.64 \pm 4.55$ & 1.161 \\
\hline University bachelor & $3.28 \pm 1.60$ & $0.048 *$ & $7.25 \pm 2.09$ & $0.001^{*}$ & $11.89 \pm 3.73$ & 0.325 \\
\hline Post graduate diploma & $2.97 \pm 1.47$ & & $6.55 \pm 2.62$ & & $11.74 \pm 3.50$ & \\
\hline Master degree & $2.60 \pm 1.48$ & & $5.71 \pm 2.10$ & & $10.87 \pm 3.71$ & \\
\hline \multicolumn{7}{|l|}{ Years of experience: } \\
\hline $1-<3$ & $2.38 \pm 1.43$ & 7.463 & $5.84 \pm 2.18$ & 4.410 & $10.98 \pm 3.47$ & 1.781 \\
\hline $3-<7$ & $3.09 \pm 1.38$ & $0.001 *$ & $6.70 \pm 2.55$ & $0.013^{*}$ & $11.54 \pm 3.63$ & 0.171 \\
\hline $7+$ & $3.38 \pm 1.67$ & & $7.01 \pm 2.25$ & & $12.12 \pm 3.84$ & \\
\hline \multicolumn{7}{|l|}{ Position of teachers: } \\
\hline Teacher & $2.91 \pm 1.46$ & 1.594 & $6.32 \pm 2.39$ & 4.503 & $11.48 \pm 3.63$ & 0.666 \\
\hline Senior teacher & $3.18 \pm 1.62$ & 0.205 & $7.08 \pm 2.24$ & $0.012 *$ & $11.78 \pm 3.69$ & 0.515 \\
\hline Activity teacher & $3.57 \pm 1.83$ & & $5.64 \pm 2.76$ & & $12.64 \pm 4.55$ & \\
\hline
\end{tabular}

*Significant $\mathrm{P}<0.05$.

Table 8. Relations of Total Scores of Knowledge, Attitude and Practice with Age among the Studied School Health Nurses about Epilepsy Post Educational Program $(n=22)$

\begin{tabular}{|c|c|c|c|c|c|c|}
\hline \multirow{3}{*}{ Variables } & \multicolumn{6}{|c|}{$\begin{array}{l}\text { Change of total scores of knowledge, attitude and practice among the studied school health nurses post-educational program } \\
(\mathrm{n}=22)\end{array}$} \\
\hline & \multicolumn{2}{|c|}{ Total knowledge scores } & \multicolumn{2}{|c|}{ Total attitude scores } & \multicolumn{2}{|c|}{ Total practice scores } \\
\hline & Mean \pm SD & $\begin{array}{l}\chi^{2} \text { value } \\
\mathbf{P}\end{array}$ & Mean \pm SD & $\begin{array}{c}\chi^{2} \text { value } \\
\mathbf{P}\end{array}$ & $\operatorname{Mean} \pm$ SD & $\begin{array}{l}\chi^{2} \text { value } \\
\mathbf{P}\end{array}$ \\
\hline Age years: & & & & & & \\
\hline $30-$ & $2.00 \pm 0.00$ & 0.660 & $5.00 \pm 0.00$ & 1.698 & $12.00 \pm 0.00$ & 0.754 \\
\hline $40-$ & $0.89 \pm 0.81$ & 0.517 & $3.95 \pm 1.93$ & 0.106 & $7.11 \pm 3.84$ & 0.460 \\
\hline $50-$ & $0.50 \pm 0.71$ & & $1.50 \pm 2.12$ & & $5.00 \pm 1.41$ & \\
\hline
\end{tabular}

$\chi^{2}$ value of Kruskal-Walis H test.

Table 8: Shows the relation between total knowledge, attitude and practice scores of the studied school health nurses with their age. The table reveals that there is an insignificant improvement in the age group $40-<50$.

\section{Discussion}

Primary school children suffering from epilepsy are often complaining from several psychological, social and learning problems because the persons around them do not know how to deals with them, that lead to negatively affecting on the children lives. Epilepsy is not only considered a medical diagnosis but also a social prognosis, which at times could be worse than the disease itself. Therefore, psycho-social aspects and the way persons around the case are dealing with them is as important as medical management of epilepsy, so that all the persons around the child should be determined how to deal with the case, and accept that epilepsy is a lifelong medical diagnosis [12].

The present study was conducted to evaluate the educational program for school health nurses and teachers 
regarding primary school children with epilepsy. As for the studied teachers' characteristics, results revealed that, slightly more than two fifths of them aged from 30 to less than 40 years; less than two third are female; near percentages representing, less than half have university bachelor education, and have 7 years of experience or more. These results agree with [13], whose study entitled: "Familiarity with and attitudes towards epilepsy among teachers at Czech elementary schools the effect of personal experience and sub-specialization in Pilsen, Czech Republic" reported that more than two third of studied teachers are female. This finding also is in accordance with that of [14] studied the "Effect of health educational program on knowledge about epilepsy and its management among primary schools' teachers in Port Said City", found that the female percentage of teachers exceeded that of the males. The researchers attributed this finding to that, generally in primary schools; teachers are females, which is the case of this study setting.

Regarding the studied school health nurses' characteristics, findings revealed that, majority of them aged from 40 to less than 50 years, all of them were female, with diploma education, and have 7 years of experience or more. These results disagree with that of [15], who studied "school nurses' experience with administration of rectal diazepam gel for seizures in Seattle, Washington" and reported that majority of the studied sample aged from 25 to less than 35 years.

Regarding school health nurses 'and teachers' knowledge, the current study results revealed that no one of the teachers had good knowledge level, and minority of school health nurses had good knowledge pre educational program, while post the educational program, more than one quarter of teachers and slightly more than two fifth of school health nurses had good knowledge level.

These previous results are congruent with those of [16], who carried out a study, in Karnataka, India, entitled: "A study to assess the effectiveness of planned teaching program on knowledge and management of epilepsy among epileptics attending outpatient department in Krishna Hospital Karad", reported that, no one of teachers had good knowledge before educational program, while nearly one third of them had good knowledge post educational program. Similarity, [17], who conducted a study in Turky, entitled "Educational program for nurses and its impact in comprehensive school nursing services on students' academic performance", mentioned that, an improvement was detected in school health nurses' knowledge after the educational program than before. From of the researchers' point of view, it may be related to that the teachers and school health nurses didn't take any training program about dealing with children suffering from epilepsy.

The present study finding revealed that the mean of total knowledge scores posttest was higher than that of pretest.This finding was in agreement with that of [18], who carried out "A Study to assess the effectiveness of planned teaching program on knowledge regarding epilepsy management in school children among primary teachers working at selected primary schools in Malur, Kolar, Karnataka" in India, which reported that the mean of total score knowledge posttest was elevated than pretest.

Concerning school health nurses' and teachers' attitudes, this study results showed that minorities of studied sample had positive attitude level pre educational program, while post the educational program, less than two thirds of teachers and most of school health nurses had positive attitude level.

These results agree with [19], whose study carried out in Saudi Arabia, entitled "Primary teacher's knowledge and attitudes toward primary school children with epilepsy" stated that minority of teachers had positive attitude before educational program, while more than two thirds of them had positive attitude after educational program. This result is at the same line with that of [17], who in a similar study mentioned that, an improvement in school health nurses' attitudes after an educational program than before. From the researchers' point of view, these findings it may be related to improvement of the school health nurses' and teachers' knowledge regarding epilepsy after implementing an educational program.

In this respect, this study referred significantly to an improvement of total scores' attitude among school health nurses and teachers toward primary school children with epilepsy after educational program. This finding could be in explained that the educational program was effective and successful in knowledge enhancement that reflected on their attitudes and behavior toward primary school children with epilepsy. This result is in agreement with that of [20], who studied "teachers' knowledge about epilepsy in Kathmandu Metropolitan City." who stated similar result.

With respect to the studied samples (school health nurses and teachers) total score practices, this study finding revealed that none of them had neither good nor moderate total score practice levels pre educational program, while more than half of both groups had moderate total score practice level post the educational program, this result convenient with that of [21], who studied "effectiveness of structured teaching program on knowledge regarding epilepsy in children among teachers", in Vijayanagar, Bangalore and mentioned that an improvement of the studied sample total score practices was found post educational program than before it.

The present study also showed that significant correlations were detected between total score knowledge and practice among school health nurses and teachers (0.001 and 0.035 respectively), while there were insignificant correlations between total practice score and total attitude score among the studied subjects regarding epilepsy post educational program.

This finding was in agreement with [22], who conducted a study in Thailand, entitled "A study of knowledge and attitude improvement on epilepsy among Thai physicians and nurses", where they demonstrated that a significant correlation was detected between total score knowledge and practices among studied samples. However the study results disagree with [23], who studied" teachers' knowledge, attitudes and practices towards seizure disorder: a comparative study of urban and rural teachers in AkwaIbom State, Nigeria", and found significant difference between total score practices and attitudes among studied samples regarding epilepsy post program.

In the same line, [24], whose study entitled "An evaluation of the management of epilepsy by primary health care nurses "in Chitungwiza, Zimbabwe and 
reported that, a positive improvement correlation was found between total score knowledge and total score practices of school health nurses regarding epilepsy. In the researchers' opinion, the educational program was effective for acquiring the school heath nurses' with knowledge and practices to deal with primary school children with epilepsy.

\section{Conclusion}

The educational program improved the school health nurses' and teachers' knowledge, attitudes and practices regarding primary school children with epilepsy. The study results also showed highly statistically significant and positive correlations between knowledge, attitudes and practices of both studied samples after the educational program implementation.

\section{Recommendations}

- Dissemination of the educational program for school health nurses and teachers at all governmental and nongovernmental schools.

- An illustrated booklet should be provided to school health nurses and teachers to be as reference in guiding them on how to deal with children with epilepsy.

- Training the newly appointed school health nurses before work how to apply the educational program for teachers to determine how to deal with children with epilepsy during and after seizure.

\section{References}

[1] Alaqeel, A.S.: Epilepsy, what do Saudi's living in Riyadh knows?, 2013, Available at: http://www.sciencedirect.com/science/article/pii/S1059131112003 317.

[2] Aydemir, N: Developing two different measures for assessing knowledge of and attitudes toward epilepsy for the Turkish population. Epilepsy Behav, PubMed; 12(1):9-84, 2013, Available at: https://www.ncbi.nlm.nih.gov/pubmed/17974487.

[3] Harden, C., Tomson, T., Gloss, D., Buchhalter, J., Cross, J.H., Donner, E., French, J.A., Gil-Nagel, A., Hesdorffer, D.C., Smithson, W.H., Spitz, M.C., Walczak, T.S., Sander, J.W., \&Ryvlin, P. : Practice guideline summary: Sudden unexpected death in epilepsy incidence rates and risk factors: Report of the guideline development, dissemination, and implementation subcommittee of the American Academy of Neurology and the American Epilepsy Society, American Academy of Neurology, PubMed; 17: 1674-1680. 2017.

[4] Tabri, A.: Parental perception of febrile convulsions. British Journal of Clinical Psychology; 38(1): 59-72. 2007.

[5] Steven, C., Greogory, L.,\&Dorothee, G.: Behaviouralaspects of epilepsy: Principles \&practice”. Demos Medical Publishing L.L.C.: pp. 366-369; 2008,

[6] Shehata, Gh.,Abd El-Lateef, Z., Ghanem, H., El-Masry, H.: Knowledge, attitude and practice regarding people with epilepsy among nurses, 2015, Available at: http://psjd.icm.edu.pl/psjd/element/bwmeta1.element.psjd58486b2d-7b96-4caf-8a83-f820126ed13d.

[7] El Tallawy, H.N., Farghaly, W.M., \&Rageh, T.A. (2010): Epidemiology of major neurological disorders project in $\mathrm{Al}$
Kharga District, New Valley, Egypt. Neuroepidemiology; 35: 291-297.

[8] World Health Organization: International Epilepsy Day, 2017, Available at:

http://www.who.int/mental_health/neurology/epilepsy/en/.

[9] Epilepsy Foundation of America: Epilepsy in children, the teacher's role, 2016, Available at:

https://www.epilepsycolorado.org/wp-content/uploads/2016/01/6The-Teachers-Role.pdf.

[10] Yamane, T: Statistics, an introductory analysis, $2^{\text {nd }}$ ed. New York: Harper and Row, chapter 7, p.p. 190: 192, 1967.

[11] Dawson, B.D., \& Trapp, R.G.: Reading the medical literature: Basic \&clinical biostatistics,New York: Lange Medical Book/ McGraw - Hill. Medical Publication Division, $3^{\text {rd }}$ ed., Ch. 7-9, pp. 161-218 and Ch. 13, pp. 305-314, 2001.

[12] Hosini, N., Sharif, F., Ahmadi, F.,\&Zare, M.: Disease- based versus patient- based approach in epilepsy management from the patients' point of view: a qualitative research. Life Science Journal; 9(3): 6-12, 2016.

[13] Brabcova, D., Lovasova, V., Kohout, J., \&Zarubova, J.: Familiarity with and attitudes towards epilepsy among teachers at Czech elementary schools the effect of personal experience and subspecialization in Pilsen, Czech Republic. British Epilepsy Association, Published by Elsevier Ltd. Seizure; 21: 461-465, 2012.

[14] Mohamed, A.M., \&Elalem, O.M.:Effect of health educational program on knowledge about epilepsy and its management among primary teachers, Department of Community \& Family Health Nursing, Faculty of Nursing, Port Said University, Egypt, International Journal of Advanced Research;53(1): 46-53, 2015.

[15] O’Dell, C., \& O’Hara, K.: School nurses' experience with administration of rectal diazepam gel for seizures in Seattle, Washington, The Journal of School Nursing; 23: 166-169, 2016.

[16] Prabhuswami, H., Vaishali, R.M., Prakash, N., Shivaji, H.P., \& Mahesh, Ch.: A study to assess the effectiveness of planned teaching programme on knowledge and management of epilepsy among epileptics attending outpatient department in Krishna Hospital Karad. International Journal of Health Sciences and Research, 11(3): 719-726; 2015.

[17] Kocoglu, D.,\&Emiroglu, O.N.: Educational program for nurses and its impact in comprehensive school nursing services on students' academic performance, in Turky. Journal of Caring Science; 6(1): 5-17, 2017.

[18] Desai, Sh., Hiremath, P., \&Naregal, P.: A study to assess the effectiveness of planned teaching programme on knowledge regarding epilepsy management in school children among primary school teachers working in selected primary schools at Malur, Kolar, Karnataka,International Journal of Health Sciences and Research, 2015, Available at: http://www.allsands.com/kids/health/epilepsychild_swy_gn.htm.

[19] Abulhamail, A.S., Al-Sulami, F.E., Alnouri, M.A., Mahrous, N.M., Joharji, D.G., Albogami, M.M., Jan, M.M.: Primary school teacher's knowledge and attitudes toward children with epilepsy, in Saudi Arabia. Seizure; 23: 280-283, 2014.

[20] Khanal, K., Maharjan, R., Pokharel, B.R, \&Sanjel S.: School teachers' knowledge about epilepsy in Kathmandu Metropolitan City. Kathmandu Univ Med.; 52(4): 316-22, 2015.

[21] Sharma, N.K., Prasanna, K.L., \& Kumar, A.: Effectiveness of structured teaching program on knowledge regarding epilepsy in children among school teachers.IOSR Journal of Nursing and Health Science; (IOSR-JNHS) e-ISSN: 2320-1959. p- ISSN: 2320-1940, Nov. - Dec. 2013; 2(6): 7-13, 2013.

[22] Locharernkul, C., Suwaroporn, S., \&Krongthong, W.: A study of knowledge and attitude improvement on epilepsy among Thai physicians and nurses. J Med Assoc Thai; 93: 875-884, 2010.

[23] Akpan, M.U., Ikpeme, E.E., \&Utuk E.E.: Teachers' knowledge, attitudes and practices towards seizure disorder: A comparative study of urban and rural school teachers in Akwalbom State, Nigeria, Nigerian Journal of Clinical Practice; 16(3): 365-370, 2013.

[24] Adamolekun, B., Mielke, J., \& Ball, D: An evaluation of the management of epilepsy by primary health care nurses in Chitungwiza, Zimbabwe. Epilepsy Res; 39: 177-181, 2011. 